\title{
Architecture Program Accreditation: A Pathway to Graduates International Mobility
}

\author{
By Sawsan Saridar Masri* \\ Hisham Arnaouty ${ }^{\prime}$
}

The education of architects as global professionals has been one of the priority goals of the Faculty of Architectural Engineering (FAE) at the Beirut Arab University for many years. It is believed that practice and education are interdependent elements of the profession that, when integrated, enable students, educators, and practitioners to obtain and maintain the knowledge and skills needed to enter and fully participate in the profession, and to achieve design excellence in service to the globalized community. Therefore, the FAE has developed its curriculum in a positive manner to integrating of education of architecture into practice, meeting the continuing challenges in the era of globalization. The aim of this paper is to evaluate the program using the validation criteria of several architecture accreditation boards. The main prospect of evaluation is that to achieve a satisfactory balance between theory and practice which implies that the study program addresses the fact that architects cannot limit themselves to conceptual analysis or virtual projects, nor to local and regional practice of the profession. Instead, graduates have the opportunity to reside their education at the crossroads between human, social, and cultural values and the technical capacities of construction of the global world.

\section{Introduction}

Architecture education in the developed countries is considered as a fundamental corner stone for the advancement of technology and applied sciences, and for being the basic foundation of knowledge and innovation. Accordingly, the institutions of higher education in the Arab world should work actively on the development of architecture education programs to keep pace with the requirements of the labor market and the industry. This policy must be accompanied with the improvement of the quality of architecture education and relative outcomes.

The increasing number of universities that teach architecture led to significant increase of graduates who are none randomly harmonious with the needs of the labor market. Subsequently, based on this reality, architecture

*Assistant Professor, Beirut Arab University, Lebanon.

${ }^{\dagger}$ Assistant Professor, Beirut Arab University, Lebanon. 
education in the Arab World and in Lebanon specifically, needs to be reevaluated.

Most universities considered quality assurance and international accreditation of their architecture programs as a priority. Besides, the Federation of Arab Engineers has decided to create an Arab Council for quality assurance and accreditation of engineering programs, including architecture programs, within the Federation. Also the Association of Arab Universities decided in 1999 to create a board for quality assurance and accreditation within the association, and this decision was approved by the seventh conference of the Arab Ministries of Higher Education held in Riyadh - KSA. In 2009, through a UNDP project, a Quality assessment of engineering programs was conducted based on detailed internal and external reviews of engineering programs in 19 Arab universities (Jammal, 2011). In addition, the increased mobility in the workspace is generating pressure to expand competencies beyond countries.

\section{Architecture Education in Lebanon}

Lebanon is one of the countries in the world that have a high ratio of institutions of higher education institutions relatively to the number of population; there are about 42 higher education institutions including universities, colleges or faculties of different specialties.

Due to the exclusiveness of architecture education for being a liberal profession so related to the labor market and subject to the terms of professional practice, there are only eight universities in Lebanon who teach architecture; one public and 7 private institutions. These universities listed in Table 1 adopt a variety of educational systems. Architecture education in Lebanon dates back to 1943 with the first school of architecture, L'Academie Libanaise des Beaux-Arts (ALBA), followed by the American University of Beirut (AUB) in 1951, and 11-15 years later by Beirut Arab University (BAU) and Lebanese University (a public institution), respectively. Later, in the last 5 decades, additional 4 private universities offered degrees in architecture: Holy Spirit University of Kaslik (USEK) in 1978, Lebanese American University (LAU) in 1993, Notre Dame University in 1999, and the latest Al-Manar University of Tripoli in 2006.

Table 1 identifies also the number of architecture students registered in 2013 at these universities with a total of 5142 . The total number of graduates for the academic year 2012/2013 is 378 , adding to them the large number of graduate of those who completed their study in architecture abroad. 
Table 1. List of Universities offering Architecture Programs in Lebanon.

\begin{tabular}{|c|c|c|c|c|}
\hline Institution & $\begin{array}{c}\text { Year of } \\
\text { launching } \\
\text { Architecture } \\
\text { Program } \\
\end{array}$ & $\begin{array}{l}\text { Program } \\
\text { Duration }\end{array}$ & $\begin{array}{c}\text { Number of } \\
\text { Registered } \\
\text { students in } \\
2014 \\
\end{array}$ & $\begin{array}{c}\text { Number } \\
\text { of } \\
\text { Graduates } \\
\text { in } 2013 \\
\end{array}$ \\
\hline $\begin{array}{c}\text { Balamand University } \\
\text { Academie Libanaise des Beaux- Arts } \\
\text { (ALBA) } \\
2 \text { branches }\end{array}$ & 1943 & $\begin{array}{l}\text { PG. } \\
\text { Diploma } \\
6 \text { years } \\
\text { (340 Euro. } \\
\text { Cr.) }\end{array}$ & 698 & 27 \\
\hline $\begin{array}{c}\text { American University of Beirut (AUB) } \\
\text { Faculty of Engineering and } \\
\text { Architecture }\end{array}$ & 1951 & $\begin{array}{c}\text { BArch. } \\
5 \text { years } \\
(174 \mathrm{Cr} .)\end{array}$ & 170 & 28 \\
\hline $\begin{array}{c}\text { Beirut Arab University (BAU) } \\
\text { Faculty of Architectural Engineering } \\
2 \text { branches }\end{array}$ & 1962 & $\begin{array}{l}\text { BArch. } \\
\text { Eng. } \\
5 \text { years } \\
(180 \mathrm{Cr} .)\end{array}$ & 645 & 80 \\
\hline $\begin{array}{c}\text { Lebanese University (UL) } \\
\text { Institue des Beaux-Arts } \\
4 \text { branches }\end{array}$ & 1966 & $\begin{array}{l}\text { MArch. } \\
5 \text { years } \\
\text { (300 Euro. } \\
\text { Cr.) }\end{array}$ & 952 & 104 \\
\hline $\begin{array}{l}\text { Holy Spirit University of Kaslik } \\
\text { (USEK) } \\
\text { Faculty of Fine and Applied Arts }\end{array}$ & 1978 & $\begin{array}{l}\text { PG. } \\
\text { Diploma } \\
6 \text { years } \\
(192 \mathrm{Cr} .)\end{array}$ & 1327 & 46 \\
\hline $\begin{array}{c}\text { Lebanese American University } \\
\text { (LAU) } \\
\text { School of Architecture and Design } \\
2 \text { branches }\end{array}$ & 1993 & $\begin{array}{l}\text { BArch. } \\
5 \text { years } \\
(176 \mathrm{Cr} .)\end{array}$ & 472 & 45 \\
\hline $\begin{array}{c}\text { Notre Dame University (NDU) } \\
\text { Faculty of Architecture, Arts and } \\
\text { Design } \\
2 \text { branches }\end{array}$ & 1999 & $\begin{array}{l}\text { BArch. } \\
5 \text { years } \\
(182 \mathrm{Cr} .)\end{array}$ & 698 & 39 \\
\hline $\begin{array}{c}\text { Al-Manar University of Tripoli } \\
\text { (MUT) } \\
\text { Faculty of Architecture and Design }\end{array}$ & 2006 & $\begin{array}{l}\text { BArch. } \\
5 \text { years } \\
(168 \mathrm{Cr} .)\end{array}$ & 180 & 9 \\
\hline \multicolumn{3}{|l|}{$\begin{array}{ll}\text { Total } \\
\end{array}$} & 5142 & 378 \\
\hline
\end{tabular}

This large amount of Architecture schools dispatched to the local and regional labor market large numbers of practitioners which exceed the needs of the Lebanese market.

Upon graduation, Lebanese architect (or architectural Engineer) has to join one of the Order of Engineers and Architects in Beirut or Tripoli, after he/she has been given a permission to practice the profession from the Ministry of Labor.

Today, the number of registered architects at the Order of Engineers and Architects in Beirut and Tripoli are respectively 6874 and 1209, with a total number of 8056 architects. This means that Lebanon has a shockingly high percentage of architects in its population: for every 496 Lebanese, one is an architect. According to the graph illustrated in Figure 1, Lebanon has the second highest ration in the world after Italy with a ratio 414 inhabitants / architect. Portugal, Denmark, Germany, Belgium, Spain, Cyprus and Greece 
all have ratios of less than 1,000 to one (Quirk, 2014). This may explain the reason why a large amount of Lebanese architects work or seek for job abroad, mostly in the UAE, Qatar, and KSA. Hence, this study will include a study of schools validated / accredited in the Middle-East and the Arab World Region.

In conclusion, this very high ratio of architects should urge architecture schools in Lebanon to enhance competition in the already tight labor market by assuring high quality of architectural education and insure regional and international mobility of their graduates through accreditation of their offered architecture programs.

Figure 1. Ratio of Architects to Inhabitants around the World (Quirk, 2014).

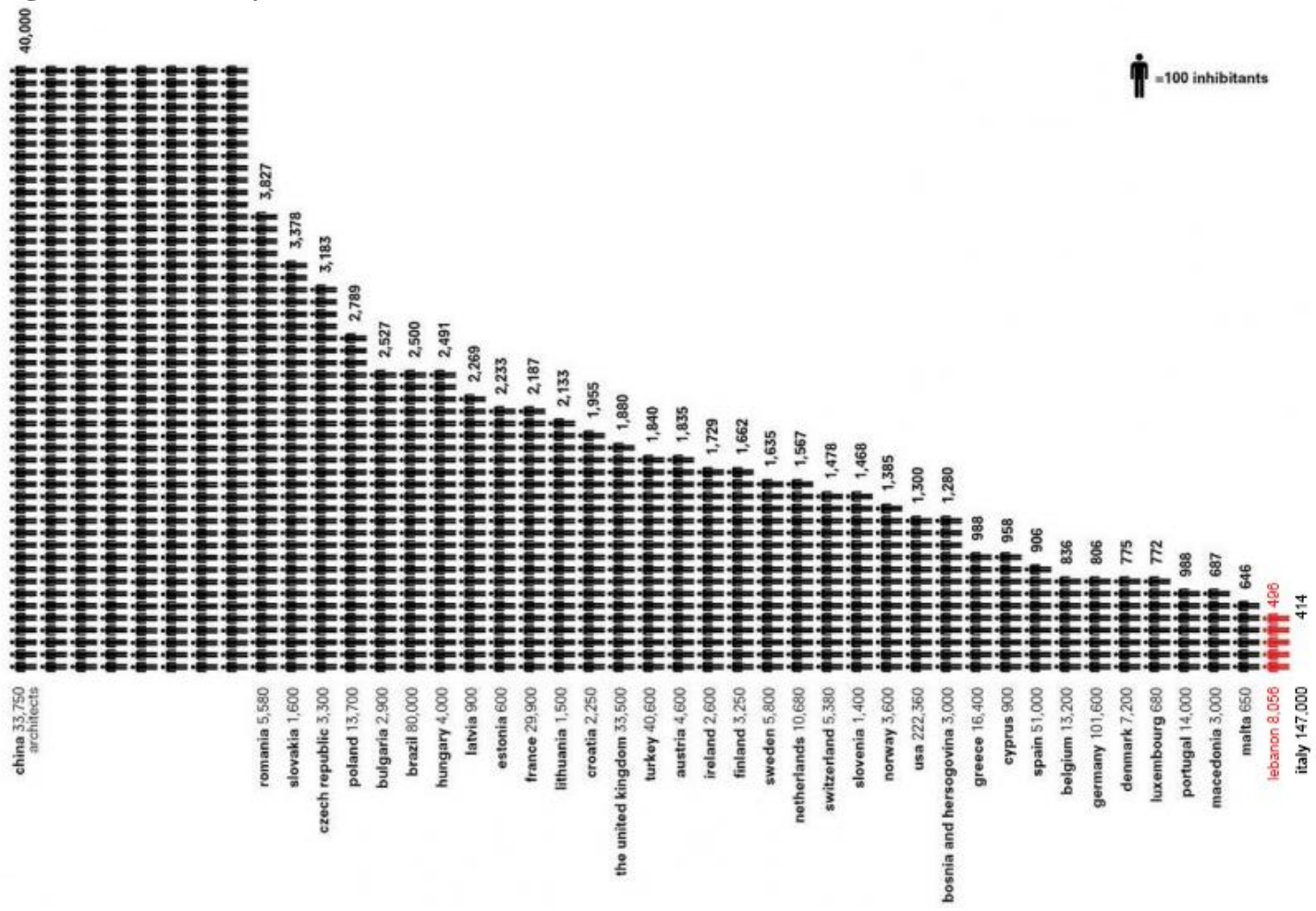

\section{Architecture Program Validation / Accreditation}

Accreditation is regarded as one of the key benchmarks for measuring the quality of academic programs. Accredited programs are deemed to be of higher quality than those which are not, thus graduate of such programs tends to be more readily accepted by the market. Given the increasing globalization, the architecture professions are no longer bounded to certain countries or region but are practicing throughout the world, thus the need for accreditation arise.

The following sub-sections will identify the internationally accredited architecture programs mainly by the RIBA, NAAB and the UIA as these accreditation bodies to which universities in the Middle East region apply to. 


\section{Understanding Difference between Validation and Accreditation}

Throughout this study, it has been noted that the words validation and accreditation are often used interchangeably. The International Union of Architects (UIA) has similar definition of the 3 terms accreditation / validation / recognition as a 'process which establishes that an educational program meets an established standard of achievement. Its purpose is to assure the maintenance and enhancement of an appropriate educational foundation' (UNESCO-UIA, 2011a).

According to the National Architectural Accrediting Board (NAAB, 2014a), the used term is accreditation, which is defined generally as a voluntary quality assurance process by which services and operations are evaluated by a third party against a set of standards established with input and collaboration from peers within the field. This U.S. model for accreditation is based on the values of independent decision-making by institutions, the ability of institutions to develop and deliver postsecondary education within the context of their mission and history, the core tenets of academic freedom, and the respect for diversity of thought, pedagogy, and methodology (NAAB, 2014a).

However, for the Royal Institute of British Architects (RIBA) there are significant differences between the two terms. The emphasis in validation is on outputs, particularly student academic portfolios (containing not just design work but also examination scripts, course work etc.) assessed against the RIBA Validation Criteria rather than teaching inputs. Hence the term validation is used to describe the outcome oriented approach of the RIBA's recognition procedures, which does not only seek to measure the inputs into a course of study. On the other hand, RIBA believes that accreditation is usually based on a number of 'input' criteria, which may include the nature of the curriculum; the quality and quantity of teaching staff; and the physical, information and technical resources. This measurement of 'inputs' is normally termed accreditation (RIBA, 2007).

\section{International Programs validated by the RIBA}

The international schools with courses recognized by the Royal Institute of British Architects (RIBA) are 31 distributed over 16 countries as follows (RIBA, 2014):

- 14 schools in Latin America; 12 of them validated for Part 1 and Part 2, and the other 2 schools validated for Part 1 only. The First 2 schools recognized by the RIBA are in Chile since 1991.

- 6 schools in Europe; 4 of them validated for Part 1 and Part 2, 1 validated for Part 1 only, and 1 is candidate for Part1. The First school recognized by the RIBA is in Bulgaria since 2004.

- 8 schools in South Asia and the Far-East; 6 of them validated for Part 1 and Part 2, and 2 schools candidate for Part 1 only. The First school recognized by the RIBA is in Singapore since 1968 followed by a school in Sri Lanka since 1986. 
- 3 schools in the Middle-East; 2 of them validated for Part 1 and Part 2, and the $3^{\text {rd }}$ one validated for Part 1 only which is Beirut Arab University in Lebanon. The First school recognized by the RIBA is in Egypt since 2004. Table 1 illustrates the detailed information of theses validated courses in the Middle-East and the Arab World.

It can be concluded that $45 \%$ of the international architecture schools recognized / validated by the RIBA are in Latin America compared to $10 \%$ in the Middle-East. On the other hand, schools in the Far-East were the first to request validation from the RIBA, and since 2004 only programs in Europe and the Middle-East started to be RIBA validated.

Table 2. Architecture Programs that are recognized by the RIBA in the Middle East and the Arab World

\section{Arab Academy of Science and Technology - Alexandria, Egypt \\ Validated Courses:}

Part 1: on completion of term 8 of BSc in Architectural Engineering and Environmental Design (4 years full time, comprising 1 year Foundation +3 years)

Part 2: on completion of terms 9 and 10 of the BSc program plus 4 terms of the graduate studies program MSc in Architectural Engineering and Environmental Design (1 year full time, plus 2 years part time)

Recognized from: 2004

Last RIBA visiting board: October 2009

Next Visit: 2014

Arab Academy of Science and Technology - Cairo, Egypt

Validated Courses:

Part 1: on completion of term 8 of BSc in Architectural Engineering and Environmental Design (4 years)

Part 2: on completion of terms 9 and 10 of the BSc program plus 4 terms of the graduate studies program MSc in Architectural Engineering and Environmental Design (1 year full time, plus 2 years part time)

\section{Recognized from:}

Part 1: 2006

Part 2: 2013

Last RIBA visiting board:

Part 1: October 2012

Part 2: March 2013

Next Visit: 2017

Beirut Arab University - Debbieh, Lebanon

Validated Courses:

Part 1: Bachelor of Architectural Engineering, 5 years full time (on completion of semester 10)

Recognized from: June 2012

Last RIBA visiting board: June 2012

Next Visit: 2017

\section{International Programs Accredited by the $N A A B$}

In order for a professional degree program in architecture to be accredited by the NAAB, the institution offering this program must be accredited by one of 6 identified regional institutional accrediting agencies for higher education 
in the U.S (NAAB, 2014a). Lebanese American University (LAU) and American University of Dubai (AUD) are the only two universities outside the U.S. who have been considered eligible for NAAB accreditation as they both have institutional accreditation from regional institutional accrediting agencies in the U.S. LAU became fully accredited since November 2009 and for five year period by the New England Association of Schools and Colleges (NEASC), and AUD became accredited since December 2007 by the Southern Association of Colleges and Schools (SACS). Table 3 represents the status of accreditation process of these two universities.

Table 3. Architecture Programs that are eligible for $N A A B$ accreditation in the Middle East.

Lebanese American University - Lebanon

Program: B.Arch.

Eligibility recognized from: 2012

Initial Candidacy: January 2013.

Candidacy Visit: Spring 2015

American University of Dubai - UAE

Program: B.Arch.

Eligibility recognized from: March 2013

Initial Candidacy: ---.

Candidacy Visit: Fall 2014

Institutions that are not accredited by a U.S. regional accrediting agency may request NAAB 'substantial equivalency' to NAAB accredited programs. The term 'substantial equivalency' identifies a program as comparable in educational outcomes in all significant aspects, and indicates that it provides an educational experience meeting acceptable standards, even though such program may differ in format or method of delivery (NAAB, 2014a).

The international schools with courses substantially equivalent to NAAB accredited programs are three: Istanbul Technical University (in 2008), Kuwait University (in 2010) and King Saud University in Saudi Arabia (in 2013). Other schools that applied for substantial equivalency are 30 distributed over 15 countries as follows (NAAB, 2014b):

- 4 schools in Latin America; 2 in Chile, 1 in Colombia, and 1 in Ecuador.

- 6 schools in Europe; 4 in Spain, and 2 in Ireland.

- 5 schools in South Asia and the Far East; 2 in India, 1 in Philippines, 1 in Bangladesh, and 1 in Thailand.

- 15 schools in the Middle East and the Arab World ; 4 in Turkey, 6 in Saudi Arabia, 2 in the UAE, 1 in Bahrain, 1 in Qatar, and 1 in Egypt which is Arab Academy for Science and Technology, and Maritime Transport whose program is already validated by the RIBA (Table 4). 
It can be concluded that $55 \%$ of the international architecture schools that are substantially equivalent or applying for substantial equivalency to NAAB accreditation in the Middle East compared to $12 \%$ in Latin America. On the other hand, schools in the Middle East were the first to request accreditation from the $\mathrm{NAAB}$, and the only substantially equivalent programs are in the Middle East as well.

Table 4. Institutions that are Substantially Equivalent or Applying for Substantial Equivalency to NAAB Accreditation in the Middle East (NAAB, 2014b).

\begin{tabular}{|c|c|c|}
\hline Institution, Country & $\begin{array}{c}\text { Most Recent } \\
\text { Activities }\end{array}$ & Next Step / Visits \\
\hline $\begin{array}{c}\text { Istanbul Technical University, } \\
\text { Turkey }\end{array}$ & Awarded Substantial Equivalency since January \\
2008
\end{tabular}


International Programs Accredited by the UNESCO-UIA

The joint UN Educational, Scientific and Cultural Organization (UNESCO) and International Union of Architects (UIA) UNESCO-UIA Validation Council for Architectural Education has been established to recognize existing and new validation systems, and to validate study programs offered at schools of architecture and other institutions.

In 2009, the Korean Architectural Accrediting Board (KAAB) and Japan Accreditation Board for Engineering Education (JABEE) became the only accrediting boards that are recognized by the UNESCO-UIA, by gaining certification from UNESCO-UIA, Validation Council for Architectural Education. As for the study programs validated by the UNESCO-UIA, there are no published list available, specifically on the UIA homepage, but according to the American University of Cairo (AUC) news, AUC architecture program is the first in the Middle East and Africa to be granted this recognition (American University of Cairo, 2014)

\section{Canberra Accord on Architectural Education}

The 'Canberra Accord on Architectural Education: Recognition of Substantial Equivalence between Accreditation / Validation Systems in Architectural Education' was signed on April 9, 2008 in Canberra, Australia. It is a document by 7 accreditation/ validation boards in architectural education. The Canberra Accord is intended to '...to facilitate international mobility of graduates in architecture and contribute to improving the quality of architectural education through benchmarking...' between the founder signatory authorities.

This accord does not address matters related to professional registration or licensure.

The first initiative for this accord was in May 2006 by the National Architectural Accrediting Board (NAAB), the National Council of Architectural Registration Boards (NCARB) and the American Institute of Architects (AIA). Architectural accrediting agencies from the U.S., Australia, Canada, China, Mexico, Korea, and the United Kingdom attended the first roundtable, as well as leaders from the Commonwealth Association of Architects and the International Union of Architects (UIA). Canada hosted the next Roundtable in 2007, and in April 2008 the following accreditation bodies signed the accord:

- The Royal Australian Institute of Architects (RAIA)

- The Royal Institute of British Architects (RIBA)

- Canadian Architectural Certification Board (CACB-CCCA)

- The National Board of Architectural Accreditation of China (NBAA)

- Commonwealth Association of Architects (CAA)

- Korean Architectural Accrediting Board (KAAB)

- Comite Mexicano para la Practica Internacional de la Arquitectura (COMPIAR) 
- Consejo Mexicano de Acreditacion de Enseñanza de la Arquitectura (COMAEA)

- US National Architecture Accreditation Board (NAAB)

In addition to contributing to the quality of architectural education through benchmarking, the core aim of the Accord is to recognize the increasingly international context within which the architect now works, and to facilitate the portability of educational credentials between signatory domains. But, because architecture is practiced in such a constrained environment governed by laws, regulations and rules, it is complicated to allow an immigrant architect to practice without an intimate and proven knowledge of local conditions, contracts, customs and ethics. For this reason professional registration - the license to practice and call oneself an architect - is not even transportable between the signatory countries, but it may assist professional mobility.

\section{Comparative Analysis between Riba, Naab \& Unesco- UIA Validation Systems}

\section{Accreditation Procedures}

The review of the validation / accreditation procedures of the RIBA, NAAB and UNESCO- UIA are summarized in Table 5. This study shows that the three boards have similar accreditation / validation process.

\section{Recommended Architecture Graduate Attributes}

According to the RIBA, the terms 'knowledge', 'understanding', 'ability' and 'skills' are used in the General and Professional Criteria to indicate the nature of achievement required as the student progresses through qualifications at Part 1 and Part 2.

The NAAB accreditation criteria encompass two levels of accomplishment:

- Understanding: The capacity to classify, compare, summarize, explain and/or interpret information.

- Ability: Proficiency in using specific information to accomplish a task, correctly selecting the appropriate information, and accurately applying it to the solution of a specific problem, while also distinguishing the effects of its implementation.

As for the UIA, the capabilities that should be acquired by architecture students during their study program are design abilities, knowledge and skills in order to become architects that are capable of fulfilling their roles as generalist who can coordinate interdisciplinary objectives (UNESCO-UIA, 2011b).

Table 6 identifies the accreditation / validation criteria and associated attributes of the three bodies. 
Table 5. Comparative study between the RIBA, UIA, and NAAB from which Most Academic Institutions in the Middle-East and the Arab World Request Accreditation / Validation for their Architecture Program.

\begin{tabular}{|c|c|c|c|}
\hline Subject of Study & RIBA & UIA & NAAB \\
\hline Since & 1924 & 2002 & 1940 \\
\hline $\begin{array}{c}\text { Scope of } \\
\text { validation / } \\
\text { accreditation }\end{array}$ & Worldwide & $\begin{array}{l}\text { Worldwide (applied only with countries } \\
\text { under UIA Charter) }\end{array}$ & $\begin{array}{l}\text { - National (Only in the US) } \\
\text { - Substantial equivalency for schools outside } \\
\text { US }\end{array}$ \\
\hline $\begin{array}{l}\text { Validation / } \\
\text { Accreditation } \\
\text { system }\end{array}$ & $\begin{array}{l}\text { Validation of architectural study programs } \\
\text { of individual institution }\end{array}$ & $\begin{array}{l}\text { - Recognition of validation system (JABEE } \\
\text { and KAAB) } \\
\text { - Validation of architectural study programs } \\
\text { of individual institution }\end{array}$ & $\begin{array}{l}\text { Validation of architectural study programs of } \\
\text { individual institution }\end{array}$ \\
\hline $\begin{array}{l}\text { Validated / } \\
\text { Accredited } \\
\text { institute }\end{array}$ & $\begin{array}{l}\text { - } 48 \text { programs in the UK } \\
\text { - } 29 \text { programs worldwide ; } 3 \text { of them are in } \\
\text { the Arab Region: } 2 \text { in Egypt and Beirut } \\
\text { Arab University (BAU) in Lebanon }\end{array}$ & $\begin{array}{l}\text { - Recognition of validation system in Japan } \\
\text { and South Korea } \\
\text { - No clear list of validated program but the } \\
\text { American University of Cairo (AUC) is } \\
\text { the first in the Arab Region }\end{array}$ & $\begin{array}{l}\text { - } 129 \text { programs in the US } \\
\text { - } 2 \text { programs eligible for accreditation in the } \\
\text { Arab Region; } 1 \text { in Lebanon (Lebanese } \\
\text { American University) and } 1 \text { in the UAE } \\
\text { (American University of Dubai) } \\
\text { - } 3 \text { programs awarded substantial } \\
\text { equivalency; } 3 \text { of them in the Arab Region } \\
\text { (Kuwait and Saudi Arabia) }\end{array}$ \\
\hline $\begin{array}{l}\text { Accreditation } \\
\text { body }\end{array}$ & $\begin{array}{l}\text { Royal Institute of British Architects - } \\
\text { Education Department, New Course } \\
\text { Group }\end{array}$ & $\begin{array}{l}\text { UNESCO UIA Charter for Architecture } \\
\text { Education } \\
\text { UIA appointed lately the RIBA to manage } \\
\text { the UNESCO-UIA validation procedures. }\end{array}$ & $\begin{array}{l}\text { The National Architectural Accrediting Board } \\
\text { (NAAB) }\end{array}$ \\
\hline
\end{tabular}




\begin{tabular}{|c|c|c|c|}
\hline $\begin{array}{l}\text { Procedures for } \\
\text { validation / } \\
\text { accreditation }\end{array}$ & $\begin{array}{l}\text { - Formally request preliminary meeting/ } \\
\text { discussion with RIBA Education } \\
\text { department } \\
\text { - Submit validated documents (self } \\
\text { assessment report \& course mapping) to } \\
\text { New Courses Group (NCG) } \\
\text { - NCG agrees to convene exploratory } \\
\text { - Eoard once first cohort completes first year } \\
\text { courseratory board recommends candidate } \\
\text { - Visiting board recommends validation. }\end{array}$ & $\begin{array}{l}\text { - Information Base Report } \\
\text { - Scheduling a visit } \\
\text { - Report group visit } \\
\text { - Preliminary report } \\
\text { - UNESCO-UIA Regional Validation } \\
\text { - Committee Report } \\
\text { - UNESCO-UIA Council Decision }\end{array}$ & $\begin{array}{l}\text { - Application to establish candidacy status. } \\
\text { - Determination of eligibility. } \\
\text { - Initial candidacy visit (Architecture Program } \\
\text { Report Submitted for Initial Candidacy } \\
\text { Visits) } \\
\text { - Request for initial accreditation } \\
\text { - Initial accreditation visit }\end{array}$ \\
\hline Period of validation & 5 years & 5 years & 6 years \\
\hline Result delivery & $\begin{array}{l}\text { - Outcomes of an exploratory visit: } \\
\circ \text { the course is given candidate course } \\
\text { status for part } 1 \text { and/or part } 2 / \text { part } 3 \\
\circ \text { the course is not given candidate course } \\
\text { status } \\
\text { Outcome of an Initial visiting board: } \\
\circ \text { the course is unconditionally validated } \\
\circ \text { the course is validated with conditions } \\
\circ \text { the course is not recommended for } \\
\text { validation, but continues as a candidate } \\
\text { course } \\
\text { exceptionally, the board may } \\
\text { recommend removal of candidate course } \\
\text { status }\end{array}$ & $\begin{array}{l}\text { - Initial Recognition/Validation } \\
\text { (unconditional, for } 5 \text { years) } \\
\text { - Conditional Recognition/Validation (for } 2 \\
\text { years, indicating the conditions to be met } \\
\text { before the next visit of the Report Group) } \\
\text { - Provisional Suspension of of } \\
\text { Recognition/Validation (suspension of the } \\
\text { agreement for } 1 \text { year, indicating the } \\
\text { conditions to be met before the next visit } \\
\text { by a Report Group) } \\
\text { - Refusal of Recognition/Validation }\end{array}$ & $\begin{array}{l}\text { - Candidacy for initial accreditation status is } \\
\text { established, in which program has } 2 \text { - } 6 \\
\text { years to obtain initial accreditation } \\
\text { - Initial Accreditation period, } 3 \text { Years } \\
\text { Program is required to achieve a } 6 \text { year term } \\
\text { for continuing accreditation in the next visit } \\
\text { Granted one of the following terms for } \\
\text { continuing accreditation } \\
\text { - Six Year term } \\
\text { - Six Year Term with focused evaluation } \\
\text { during the first } 1,2 \text { or } 3 \text { years } \\
\text { - Three Years Term } \\
\text { - Two Year Probationary Term } \\
\text { - Revocation of accreditation: Program was } \\
\text { able to achieve a term for continuing } \\
\text { accreditation during the visit after a Two- } \\
\text { Year Probationary Term. } \\
\text { - Substantial equivalency }\end{array}$ \\
\hline
\end{tabular}


Table 6. Comparative Study between the Architecture Graduate Attributes recommended by RIBA, UIA, and NAAB.

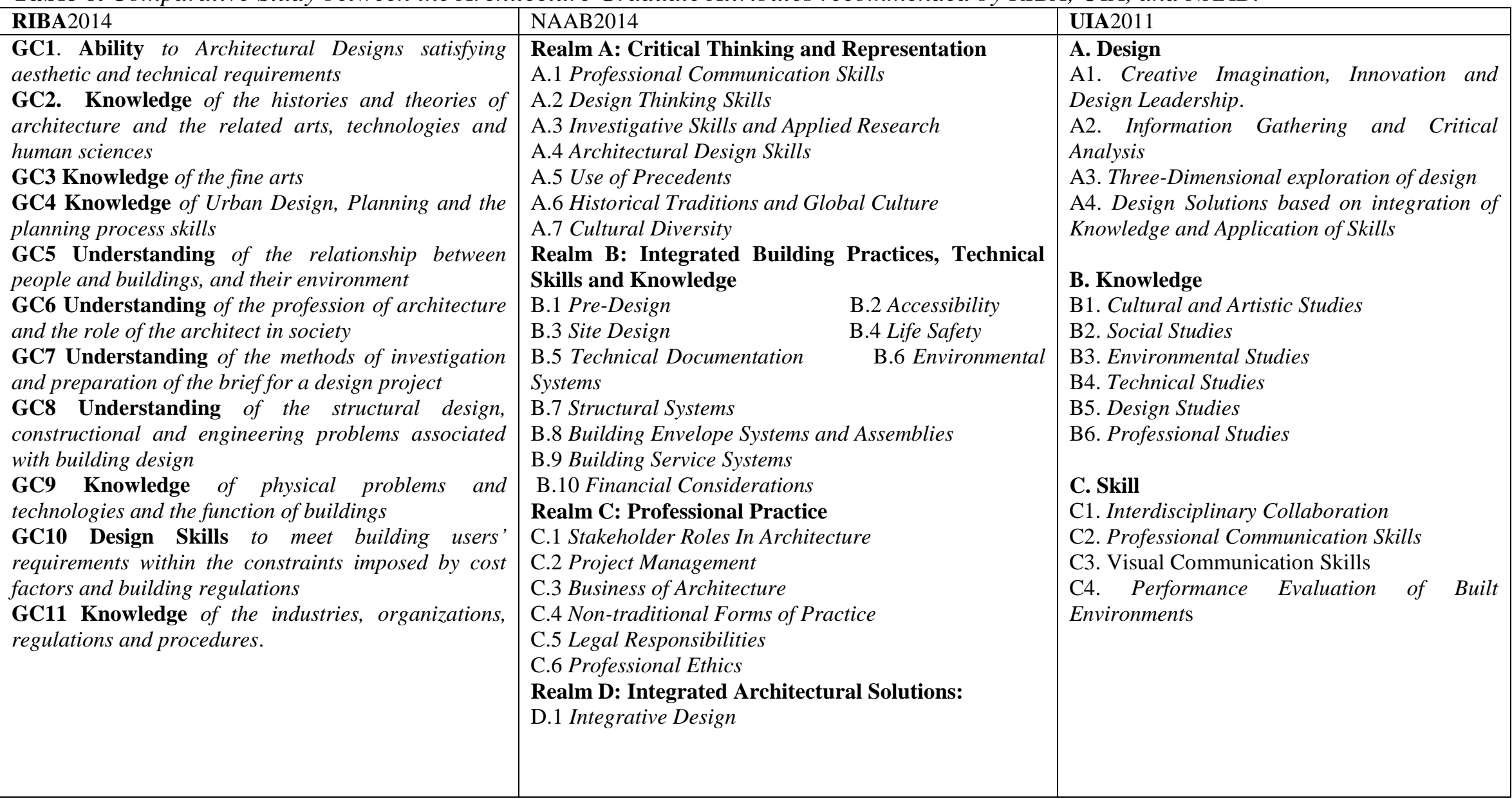




\section{Conclusions}

Through reviewing the international accreditation / validation tendencies of architecture programs in Lebanon and the Arab World, it has been noticed that most of them went toward NAAB accreditation. This was not the case of BAU who selected to be validated by the RIBA. Nevertheless, BAU has the opportunity to apply for NAAB Substantial Equivalency as the Arab Academy for Science and Technology, and Maritime Transport in Egypt which is also accredited by the RIBA. This will facilitate the mobility of its graduate to the Regional market at the first level ; namely Saudi Arabia, Kuwait, United Arab Emirates and Qatar; where most of their institutions are targeting NAAB Substantial Equivalency.

The paper has also shown that institutional accreditation open the scope of international mobility and programs' accreditation.

This paper also recommends that Arabic countries should benefit from the expertise of those countries around the world to establish their own Arab Architecture Accreditation / Validation Board. Arab architectural education systems need to develop their own model based on their climate and culture, but also adapt to what is in the market.

On the other hand, it is recommended that the Federation of Arab Engineers reviews the condition procedures, and evaluation criteria of the Arab Council for quality assurance and accreditation of engineering programs in order to comply with the international standards, and be eligible to join the Canberra Accord, or be recognized by the UNESCO- UIA Charter for Architecture Education.

\section{Acknowledgments}

Our thanks to Professor Amr El-Adawi, President of BAU, for his incessant efforts towards quality assurance and international recognition of BAU.

\section{References}

American University of Cairo. 2014. Architecture Program First in Region to Receive Global Validation. DOI= http://www.aucegypt.edu/newsatauc/pages/ Story.aspx? storyID=1415.

Jammal, A. 2011. Engineering Education in Lebanon: Toward Quality Assurance and Accreditation. Ideas for better Education and training for Engineers. 11 (Dec. 2011), 13-26.

NAAB. 2014a. 2014 Conditions for Accreditation - First Draft. DOI= http://www .naab.org/documents/streamfile. aspx? sortfield=lastmodified!asc\&name $=2013+\mathrm{N}$ AAB+Conditions+First+Draft_Combined+File.pdf\&path=Public+Documents\% 5 CAccreditation\%5C.

NAAB. 2014b. Summary of Recent Activities - May 30, 2014. DOI= http://www.aia. org/aiaucmp/groups/aia/documents/pdf/aiab103904.pdf. 
Quirk, V. 2014. Does Italy Have Way Too Many Architects? (The Ratio of Architects to Inhabitants Around the World). DOI = http://www.archdaily.com/501477/do es-italy-have-way-too-many-architects-the-ratio-of-architects-to-inhabitants-arou nd-the-world/.

RIBA. 2014. International Schools with courses recognized by the RIBA-Information Updated: 26 June 2014. DOI= http://www.architecture.com/Files/RIBAProfes sionalServices/Education/Validation/InternationalValidation/InternationalSchools List2013.pdf.

RIBA. 2011. RIBA Procedures for Validation and Validation criteria for UK and International Courses and Examinations in Architecture. DOI= http://www.archi tecture.com/Files/RIBAProfessionalServices/Education/Validation/ValidationPro cedures2011.pdf.

RIBA. 2007. RIBA Principles \& Procedures for the Validation of International Courses and Examinations in Architecture. DOI= http://www.architecture.com /Files/RIBAProfessionalServices/Education/Validation/InternationalValidation/R IBA\%20International\%20Validation\%20Procedures.pdf.

UNESCO-UIA. 2011a. UIA Accord on Recommended International Standards of Professionalism in Architectural Practice. DOI= http://www.aia.org/aiaucmp/ groups/aia/documents/pdf/aias075164.pdf.

UNESCO-UIA. 2011b. UNESCO-UIA system for Architectural Education. DOI= uiaarchitectes.org/sites/default/files/ENValid2011NEWGraphicC.pdf. 
